\title{
PROFIL MANAJEMEN BIMBINGAN DAN KONSELING DI SEKOLAH MENENGAH ATAS
}

\author{
Triyono $^{1}$, Rahmi Dwi Febriani ${ }^{2}$, Veni Novalia ${ }^{3}$ \\ Program Studi Bimbingan dan Konseling STKIP PGRI Sumatera Barat \\ triono@stkip-pgri-sumbar.ac.id
}

\begin{abstract}
Self development activities are educational activities outside the subjects that help schools in shaping the character and personality of learner. Self-development activities are facilitated and guided by counselor, teachers, or educational personnel that can be done in the form of extracurricular activities. In the implementation of guidance and counseling is never separated from careful planning and systematic. A program of guidance and counseling services in school is unlikely to be established, organized and achieved if not managed in a quality management system. Management guidance and counseling are all efforts or ways used to optimally utilize all components or resources such as personnel, funds and infrastructure facilities and information systems in the form of guidance data set to provide guidance and counseling services in order to achieve goals. The principles of guidance and counseling management services include planning, organizing, staffing, leading \& controlling.
\end{abstract}

Keyword: Guidance and Counseling Management

\section{PENDAHULUAN}

Penyelenggaraan pendidikan yang bermutu dan efektif adalah mengintegrasikan tiga komponen sistem pendidikan salah satunya adalah bimbingan dan konseling. Bimbingan dan konseling diselenggarakan di sekolah dalam rangka mencapai tujuan pendidikan untuk memfasilitasi perkembangan peserta didik/konseli agar mampu mengaktualisasikan potensi dirinya atau mencapai perkembangan secara optimal.

Upaya untuk mewujudkan potensi peserta didik/konseli menjadi kompetensi dan prestasi hidup memerlukan sistem layanan pendidikan integratif.

Bimbingan dan konseling bagian yang terintegrasi dengan pendidikan. Berdasarkan (Panduan Operasional BK, 2016) Bimbingan dan konseling merupakan upaya sistematis, objektif, logis, dan berkelanjutan serta terprogram yang dilakukan oleh guru BK/konselor untuk memfasilitasi perkembangan peserta didik/konseli dalam mencapai kemandirian

Menurut (Zamroni \& Rahardjo, 2015) pelaksanaannya bimbingan dan 
konseling tidak pernah lepas dari perencanaan yang seksama dan bersistem. Sebagai suatu kegiatan, apabila dilakukan secara sembarangan, tidak terencana, dapat dipastikan hasilnya tidak akan diketahui secara pasti. Apabila bimbingan dan konseling tidak dilakukan secara terencana dan sembarangan maka tidak akan dapat diketahui seberapa hasil yang telah dicapai dalam konteks kontribusinya bagi pencapaian tujuan pendidikan di sekolah.

Bimbingan dan konseling
memiliki konsep dan peran yang
ideal, karena dengan berfungsinya
bimbingan dan konseling secara
optimal semua kebutuhan dan permasalahan siswa di sekolah akan dapat ditangani dengan baik (Triyono \& Febriani, 2018b). Suatu program pelayanan bimbingan dan konseling di sekolah tidak mungkin akan tersusun, terselenggara dan tercapai apabila tidak dikelola dalam suatu sistem manajemen yang bermutu. Manajemen yang bermutu adalah ditemukannya kemampuan manajer pendidikan di sekolah dalam merencanakan, mengorganisasikan, mengarahkan, dan mengendalikan sumberdaya yang ada (Anni, 2012).

Optimalisasi pelayanan bimbingan dan konseling perlu dilakukan sehingga pelayanan binbingan dan konseling benar-benar memberikan kontribusi pada penetapan visi, misi, dan tujuan sekolah yang bersangkutan (Triyono \& Febriani, 2018a). Pada prinsipnya manajemen memuat makna segala upaya menggerakkan individu atau kelompok untuk bekerja sama dalam mendayagunakan sumber daya dalam suatu sistem untuk mencapai tujuan. Menurut (Zamroni \& Rahardjo, 2015) manajemen bimbingan dan konseling adalah segala upaya atau cara yang digunakan untuk mendayagunakan secara optimal semua komponen atau sumber daya seperti tenaga, dana dan sarana prasarana serta sistem informasi berupa himpunan data bimbingan untuk menyelenggarakan pelayanan bimbingan dan konseling dalam rangka mencapai tujuan.

Adapun prinsip-prinsip dalam manajemen pelayanan bimbingan dan konseling meliputi planning, organizing, actuating, dan controlling Manajemen bimbingan dan konseling merupakan salah satu kompetensi dasar yang harus dikuasai oleh konselor. Manajemen bimbingan dan konseling yang terarah dan sistematis merupakan manifestasi dan akumulasi pelayanan bimbingan dan konseling sehingga merupakan salah satu indikator kerja konselor.

Fakta di lapangan yang ditemukan pada sebuah sekolah di kota Padang dimana manajemen di sekolah tersebut belum sesuai dengan prinsip pelayanan bimbingan dan konseling yang semestinya. Hal ini terlihat dari belum matangnya perencanaan dalam penyusunan program bimbingan dan konseling, pelaksanaan, pengorganisasi seperti belum jelasnya struktur organisasi bimbingan dan konseling dan pembagian tugas setiap personil. 
Namun pengawasan terhadap manajemen bimbingan dan konseling sudah dijalankan sekali setiap satu semester oleh pengawas dari dinas pendidikan dan kepala sekolah setiap minggunya.. Hanya saja hal yang merusak manajemen bimbingan dan konseling di sekolah ini yaitu mengenai sarana dan prasana yang belum memadai, pembiayaan yang belum mencukupi, evaluasi terhadap program yang belum terjalani serta kinerja personil bimbingan dan konseling di sekolah tersebut belum maksimal.

Berdasarkan fakta di atas, manajemen bimbingan dan konseling di sekolah dapat dikatakan belum maksimal, maka urgensi artikel ini yaitu untuk melihat profil manajemen bimbingan dan konseling di SMA Negeri 9 Padang. Dengan demikian artikel ini akan membantu dalam memperbaiki manajemen bimbingan dan konseling di sekolah dari sudut pandang ilmu bimbingan dan konseling.

Berdasarkan latar belakang di atas maka masalah pokok dalam penelitian ini dirumuskan sebagai berikut "Bagaimana profil manajemen bimbingan dan konseling di SMA Negeri 9 Padang?". Tujuan penelitiannya yaitu untuk mendeskripsikan profil manajemen bimbingan dan konseling di sekolah dilihat dari aspek: a) Perencanaan, b)pelaksanaan, c) pengorganisasian, d) pepengawasan, e) akuntabilitas, dan f) faktor penghambat dan faktor pendukung bimbingan dan konseling di sekolah.

\section{METODE PENELITIAN}

Penelitian dilaksanakan di SMA Negeri 9 Padang, menggunakan metode penelitian kualitatif jenis deskriptif. Informan penelitian adalah satu orang guru bimbingan dan konseling di SMA Negeri 9 Padang. Teknik pengumpulan data yang digunakan dalam penelitian ini yaitu dengan wawancara. Teknik analisis data yang digunakan yaitu reduksi data, penyajian data dan penarikan kesimpulan.

\section{HASIL DAN PEMBAHASAN}

Berdasarkan hasil wawancara yang dilakukan di SMA Negeri 9 Padang pada tanggal 21 November 2017 maka mendapatkan hasil bahwa perencanaan program pelayanan bimbingan dan konseling di SMA Negeri 9 Padang tersusun secara sistematis. Hal tersebut dapat diketahui dari penyusunan program tahunan, program semesteran, program bulanan, program mingguan dan program harian. Pada penyusunan program pelayanan bimbingan dan konseling, guru BK/konselor terlebih dahulu melakukan studi kebutuhan atau need assessment yang diperoleh melalui aplikasi instrumentasi.

Need assessment atau asesmen kebutuhan merupakan proses yang kompleks dan tidak mudah dilaksanakan (Anni, 2012). Rasio guru bimbingan dan konseling dengan siswa sebesar 1:150 (Depdiknas, 2007) juga menjadi kerumitan dalam melakukan asesmen kebutuhan. 
Penyusunan program bimbingan dan konseling terdiri dari jenis kegiatan, seperti jenis layanan BK dan kegiatan pendukung. Adapun jenis-jenis layanan yang diberikan yaitu layanan orientasi, informasi, penempatan dan penyaluran, penguasaan konten, konseling perorangan, bimbingan kelompok, konseling kelompok, konsultasi, dan mediasi. Sedangkan kegiatan pendukung bimbingan dan konseling yang digunakan yaitu aplikasi instrumentasi, himpunan data, konferensi kasus, kunjungan rumah, tampilan kepustakaan dan alih tangan kasus.

Penyusunan program bimbingan dan konseling tersebut disusun berdasarkan materi bidang pengembangan. Adapun bidang-bidang pengembangannya seperti bidang bimbingan pribadi, sosial, belajar dan bidang bimbingan karir.

Program yang telah disusun akan dijabarkan dari program tahun, semesteran, bulanan, minggu hingga program harian. Sedangkan perencanaan format kegiatan pada program pelayanan bimbingan dan konseling di SMA Negeri 9 Padang sebagai berikut individual, yaitu format kegiatan konseling yang melayani peserta didik secara perorangan, kelompok yaitu format kegiatan konseling yang melayani sejumlah peserta didik melalui suasana dinamika kelompok, klasikal yaitu format kegiatan konseling yang melayani sejumlah peserta didik dalam satu kelas, lapangan yaitu format kegiatan konseling yang melayani seorang atau sejumlah peserta didik melalui kegiatan di luar kelas atau lapangan, pendekatan khusus, yaitu format kegiatan konseling yang melayani kepentingan peserta didik melalui pendekatan kepada pihak-pihak yang dapat memberikan kemudahan.

Adapun pelaksanaan pelayanan bimbingan dan konseling di SMA Negeri 9 Padang yaitu satu kali kegiatan layanan atau kegiatan pendukung konseling berbobot ekuivalen 2 (dua) jam pembelajaran, volume keseluruhan kegiatan pelayanan konseling dalam satu minggu minimal ekuivalen dengan beban tugas wajib konselor di sekolah, program pelayanan konseling yang direncanakan dalam bentuk Satuan Layanan atau SATLAN dan Satuan Pendukung atau SATKUNG dilaksanakan sesuai dengan sasaran, substansi, jenis kegiatan, waktu, tempat, dan pihakpihak yang terkait. Pelaksanaan kegiatan pelayanan konseling di dalam jam pembelajaran sekolah dan di luar jam pembelajaran sekolah.

Pengorganisasian bimbingan dan konseling di SMA Negeri 9 Padang telah tersusun secara sistematis. Adapun pengorganisasian bimbingan dan konseling di SMA Negeri 9 Padang seperti adanya personil-personil bimbingan dan konseling yang saling bekejasama untuk kelancaran dari proses pelayanan bimbingan dan konseling di sekolah tersebut. Personil- personil bimbingan dan konseling bekerja sesuai dengan tugas dan tanggung 
jawab yang menjadi wewenang dari masing- masing personil.

Pengawasan pelayanan

bimbingan dan konseling di SMA Negeri 9 Padang yaitu kegiatan pelayanan konseling di sekolah dipantau, dievaluasi, dan dibina melalui kegiatan pengawasan, pengawasan kegiatan pelayanan konseling dilakukan secara interen oleh kepala sekolah dan eksteren oleh pengawas sekolah bidang konseling.

Fokus pengawasan adalah untuk melihat kemampuan profesional konselor dan implementasi kegiatan pelayanan konseling yang menjadi kewajiban dan tugas konselor di sekolah, pengawasan kegiatan pelayanan konseling dilakukan secara berkala dan berkelanjutan serta hasil pengawasan didokumentasikan, dianalisis, dan ditindaklanjuti untuk peningkatan mutu perencanaan dan pelaksanaan kegiatan pelayanan konseling di sekolah. Sedangkan pengawasan oleh pengawas dari dinas pendidikan dilaksanakan sekali dalam satu semester.

Akuntabilitas layanan BK di SMA Negeri 9 Padang yaitu di laksanakannya akuntabilitas program dan manajemen. Akuntabilitas program yaitu mengacu pada pertanggung jawaban berkenaan dari hasil kegiatan bimbingan dan konseling yang telah dilaksanakan. Guru BK di sekolah tersebut telah bertanggung jawab terhadap hasil kegiatan bimbingan dan konseling yang dilaksanakan yaitu diadakannya penilaian dan tindak lanjut dari layanan yang diberikan kepada siswa.
Sedangkan akuntabilitas manajemen menitik beratkan pada efisiensi dan efektifitas dalam penggunaan dana, fasilitas, SDM dan sumber daya lainnya. Akuntabilitas manajemen di SMA Negeri 9 Padang ini dapat dirinci lagi menjadi akuntabilitas keuangan, fasilitas, administrasi, dan sumber daya manusia.

Faktor penghambat dan pendukung bimbingan dan konseling di SMA Negeri 9 Padang. Pertama, faktor penghambat pelayanan bimbingan dan konseling yaitu waktu, hambatan ini disebabkan karena bimbingan dan konseling tidak diberikan waktu untuk melakukan pelayanan sesuai dengan waktu yang ditetap dalam program.

Sedangkan pada program pelayanan bimbingan dan konseling dilakukan 2 (dua) jam pembelajaran dalam melakukan satu kegiatan layanan. Hal ini menyebabkan proses pemberian layanan tidak efektif sehingga tujuan dalam layanan tersebut tidak tercapai. Biaya juga menjadi faktor penghambat bagi kelancaran pelayanan bimbingan dan konseling di sekolah.

Hal ini disebabkan dalam pembuatan program, guru BK sangat membutuhkan biaya dalam menyusun program terutama dalam mencetak progam tersebut. Selain itu, biaya juga diperlukan dalam pelaksanaan program tersebut. Akan tetapi pembiayaan bimbingan dan konseling di sekolah tersebut belum disediakan secara khusus oleh pihak sekolah. Sarana dan prasana bimbingan dan konseling juga belum memadai 
seperti belum adanya ruangan konseling kelompok, ruangan konfrensi kasus. Ruangan yang tersedia hanya ruangan konseling perorangan yang dikategorikan belum memadai. Sedangkan alat untuk pengumpulan data, penyimpanan data, sarana teknis, sarana teknis pelaksanaan, dan sarana tata laksana bimbingan sudah disediakan, namun belum memadai.

Adapun faktor pendukung pelaksanaan bimbingan dan konseling di SMA Negeri 9 Padang yaitu siswa secara aktif dan sukarela datang ke ruangan bimbingan dan konseling sehingga program yang telah disusun dapat berjalan dengan baik dan efektif. Dengan demikian, program yang telah disusun dapat dilaksanakan sesuai dengan waktu yang telah ditentukan dengan jenis kegiatan dan materi bidang pengembangan yang telah ditetapkan.

Menurut (Febriani \& Triyono, 2018) setiap kegiatan bimbingan dan konseling dilaksanakan melalui tahap perencanaan kegiatan, pelaksanaan kegiatan, penilaian hasil kegiatan analisis hasil penilaian dan tindak lanjut. Hal ini tentu saja tidak terlepas dari manajemen bimbingan dan konseling.

Beberapa hal yang harus dilaksanakan dalam manajemen bimbingan dan konseling sehingga pelayanan bimbingan dan konseling dapat berjalan dengan baik yaitu adanya perencanaan program yang sesuai dengan kebutuhan peserta didik, pelaksanaan bimbingan dan konseling yang sesuai dengan program yang telah direncanakan, pengorganisasian bimbingan dan konseling yang jelas sehingga setiap personil memiliki tugas dan tanggung jawabnya masing-masing dalam pelaksanaan pelayanan, kepengawasan bimbingan dan konseling yang dilakukan secara berkala, akuntabilitas bimbingan dan konseling yang dilaksanakan secara baik oleh personil bimbingan dan konseling, meminimalisir faktor penghambat dan melengkapi faktor pendukung bimbingan dan konseling di sekolah.

\section{KESIMPULAN}

Berdasarkan hasil pembahasan di atas maka dapat disimpulkan bahwa manajemen bimbingan dan konseling di SMA Negeri 9 Padang cukup baik. Hal ini tergambar dari perencanaa, pelaksanaan, pengorganisasian, kepengawasan dan akuntabilitas bimbingan dan konseling di sekolah tersebut sudah berjalan sesuai dengan prinsip serta aturan dari pelayanan bimbingan dan konseling semestinya. Akan tetapi manajemen di sekolah tersebut sangat di pengaruhi oleh faktor penghambat yang menjadikan manajemen bimbingan dan konseling tidak efektif di sekolah tersebut dan faktor pendukung bimbingan dan konseling yang berkontribusi dalam melancarkan jalannya manajemen bimbingan dan konseling di SMA Negeri 9 Padang.

Program bimbingan dan konseling di SMA Negeri 9 Padang mempunyai tujuan untuk membantu 
siswa dalam usaha pengembangan kehidupan pribadi, sosial, belajar dan bidang karir. Dalam pelayanan dan konseling diharapkan siswa mampu untuk mencapai pengembangan potensi yang dimiliki secara optimal. Dalam pelaksanaan program yang ada pada layanan bimbingan konseling di SMA Negeri 9 Padang adanya partisipasi dan dukungan pihak yang terkait antara lain pihak sekolah yaitu bantuan dan dukungan material dan spritual demi tercapainya suasana pendidikan yang menyenangkan, guru dan wali kelas dapat kontribusi dalam penanganan membantu permasalahan yang dialami oleh siswa, tenaga kependidikan yang ada di sekolah agar turut berperan serta dalam pelaksanaan dibidang administrasi yang dibutuhkan, peran serta siswa, dan seluruh unsur-unsur yang ada disekolah agar dapat memahami dan menempatkan fungsi bimbingan konseling secara nyata, ikhlas dan penuh rasa tanggung jawab.

$$
\text { Dengan demikian dapat }
$$

disimpulkam bahwa bimbingan dan konseling di SMA Negeri 9 padang sesuai dengan prinsip-prinsip dalam manajemen pelayanan bimbingan dan konseling meliputi planning, organizing, staffing, leading \& controlling, hanya saja penerapannya yang belum maksimal.

\section{DAFTAR RUJUKAN}

Anni, C. T. (2012). Need Assesment Model Penyusunan Program Bimbingan dan Konseling Bidang Bimbingan Belajar
Berbantuan Sistem Informasi Manajemen Di SMA Negeri Kota Semarang. Educational Management, 1(1).

Depdiknas. 2006. Permendiknas Nomor $22 / 2006$ tentang Standar Isi untuk Satuan Pendidikan Dasar dan Menengah. Jakarta: Depdiknas.

Febriani, R. D., \& Triyono, T. (2018). Faktor Penghambat Pelaksanaan Evaluasi Program Bimbingan dan Konseling oleh Guru Bimbingan dan Konseling. Jurnal Counseling Care, 2(1), 21-27.

Kartadinata, Sunaryo. 2004. Arah dan

Tantangan Bimbingan dan Konseling Profesional: Proposisi Historik-Futuristik. Bandung: UPI.

Peraturan Menteri Pendidikan dan Kebudayaan Republik Indonesia Nomor 111 Tahun 2014 Tentang Bimbingan dan Konseling Pada Pendidikan Dasar dan Pendidikan Menengah. Jakarta: Kemdikbud.

Panduan Operasional BK. (2016). Panduan Operasional Penyelenggaraan Bimbingan dan Konseling Sekolah Menengah Atas |i.

Triyono, T., \& Febriani, R. D. (2018a). Pentingnya Pemanfaatan Teknologi Informasi oleh Guru Bimbingan dan Konseling. JUANG: Jurnal Wahana Konseling, 1(2).

Triyono, T., \& Febriani, R. D. (2018b). Persepsi Peserta Didik Sekolah Menengah Atas Terhadap Pendidikan Lanjutan. 
Edudikara: Jurnal Pendidikan

Dan Pembelajaran, 3(1), 70-77.

Zamroni, E., \& Rahardjo, S. (2015).

Manajemen bimbingan dan

konseling berbasis permendikbud

nomor 111 tahun 2014. Jurnal

Konseling Gusjigang, 1(1). 